\title{
The Herdecke questionnaire on quality of life (HLQ): Validation of factorial structure and development of a short form within a naturopathy treated in-patient collective
}

\author{
Thomas Ostermann*1, Arndt Büssing1, Andre-Michael Beer ${ }^{2}$ and \\ Peter F Matthiessen ${ }^{1}$
}

\begin{abstract}
Address: ${ }^{1}$ Chair of Medical Theory and Complementary Medicine, Faculty of Medicine, University of Witten/Herdecke, Germany and ${ }^{2}$ Department of Naturopathy, Blankenstein Hospital, Hattingen, Germany

Email: Thomas Ostermann* - thomaso@uni-wh.de; Arndt Büssing - arbuess@yahoo.de; Andre-Michael Beer - andre.beer@klinikblankenstein.de; Peter F Matthiessen - peter.matthiessen@uni-wh.de

* Corresponding author
\end{abstract}

Published: 08 July 2005

Health and Quality of Life Outcomes 2005, 3:40 doi:10.1 I86/1477-7525-340

This article is available from: http://www.hqlo.com/content/3///40

(C) 2005 Ostermann et al; licensee BioMed Central Ltd.

This is an Open Access article distributed under the terms of the Creative Commons Attribution License (http://creativecommons.org/licenses/by/2.0), which permits unrestricted use, distribution, and reproduction in any medium, provided the original work is properly cited.
Received: 10 June 2005

Accepted: 08 July 2005

\begin{abstract}
Background: Quality of life (QoL) of patients has become a central evaluation parameter that also acts as an aid for decisions related to treatment strategies particularly for patients with chronic illnesses. In Germany, one of the newer instruments attempting to measure distinct QoL aspects is the "Herdecke Questionnaire for Quality of Life" (HLQ). In this study, we aimed to validate the HLQ with respect to its factorial structure, and to develop a short form. The validation has been carried out in relation to other questionnaires including the SF-36 Health Survey, the Mood-Scale Bf-S, the Giessen Physical Complaints Questionnaire GBB-24 and McGill's Pain Perception Scale SES.
\end{abstract}

Methods: Data for this study derived from a model project on the treatment of patients using naturopathy methods in Blankenstein Hospital, Hattingen. In total, 2,46I patients between the ages of 16 and 92 years (mean age: $58.0 \pm 13.4$ years) were included in this study. Most of the patients $(62 \%)$ suffered from rheumatic diseases. Factorial validation of the HLQ, it's reliability and external consistency analysis and the development of a short form were carried out using the SPSS software.

Results: Structural analysis of the HLQ-items pointed to a 6-factor model. The internal consistency of both the long and the short version is excellent (Cronbach's $\alpha$ is 0.935 for the HLQ$\mathrm{L}$ and 0.862 for the HLQ-S). The highest reliability in the HLQ-L was obtained for the "Initiative Power and Interest" scale, the lowest for the 2-item scales "Digestive Well-Being" and the "Physical Complaints". However, the scales found by factor analysis herein were only in part congruent with the original 5-scale model which was approved a multitrait analysis approach. The new instrument shows good correlations with several scales of other relevant QoL instruments. The scales "Initiative Power and Interest", "Social Interaction", "Mental Balance", "Motility", "Physical Complaints", "Digestive Well-Being" sufficiently differentiate the diagnostic groups, particularly 
between the patients suffering on connective tissue and soft tissue disorders from those with metabolic and nutritional disorders or hypersensitivity reactions.

Conclusion: Both the factorial validation and the development of a consistent short-form of the HLQ are important steps forward for researchers in the field of QoL who wish to use the HLQ as a reliable and valid instrument. The results indicate that the HLQ is a unique QoL-instrument that can be used for both in-patient and out-patient-treatment. However, to improve to profile of the HLQ, there is still the need for strengthening the Questionnaire in the dimensions of physical wellbeing. This is the subject of a separate ongoing study.

\section{Background}

The consideration of "quality of life" (QoL) in clinical studies and various attempts to make this construct measurable to determine therapeutic success is an ongoing process. This is particularly the case in those therapeutic attempts that focus on integrative aspects of disease management that in turn offer holistic care including a variety of therapeutic directions. Here, the QoL has become a central evaluation parameter. It simultaneously acts as an aid for decisions on the choice of treatment strategy for chronically ill patients [1], which is obviously a challenging therapeutic aim, and is at least as significant as somatic parameters [2]. QoL has therefore become a leading criteria in many outcome studies alongside somatic and economic factors. In the course of this development, the concept of QoL is explicitly listed as outcome parameter in many medical societies' guidelines [3].

However, there are a variety of opinions regarding the factors that contribute to QoL. According to a WHO-definition, QoL relates to the physical, psychological and social well-being of an individual as laid out by formal health terms [4]. According to this definition, it is necessary to differentiate between a general and a health related QoL [5]. The former relates to aspects that exist independently from any particular disease (e.g. items such as "being spontaneous", or "feeling exhausted"), whereas the later focuses on particular characteristics of specific diseases (e.g. factors such as "walking distance" or "pain" in rheumatic diseases)

Despite the methodological difficulties involved in making QoL measurable, we have seen the development of numerous instruments for measuring disease specific aspects of QoL [6-8] in the recent past. An advantage of disease specific instruments is precise registration regarding strains and limitations of specific diseases rather than those of diseases in general. In addition, the course of clinical diseases can be more easily registered because of the development of disease-related questionnaires ("course of disease sensitivity" of questionnaires). The majority of current recommendations by health economists and clinical pharmacological associations include suggestions regarding the use of disease specific and general QoL questionnaires [9].

In Germany, one of the newer instruments attempting to measure general QoL with a distinct focus is the "Herdecke Questionnaire for Quality of Life" (HLQ is the German acronym of the phrase "Herdecke Questionnaire for Quality of Life") [10,11]. Clinical research projects have been reluctant to employ the HLQ although it was evaluated on a sample of healthy subjects, and that some reference values of clinical studies on different diseases do exist, and also despite of the fact that the HLQ has a very comprehensive understanding of the QoL problematic [12],. This is mainly because conclusive validation based on a large sample is still missing. To improve this situation, this study aimed to show the characteristics of the HLQ, to describe its external validation using other test instruments, and to develop a short form of the questionnaire.

\section{Methods}

Data for this study derive from a model project on the treatment of patients using naturopathy methods in Blankenstein Hospital, Hattingen. To investigate the benefits and limits of naturopathic treatment in the field of in-patient care, the Department of Naturopathy was established as a model at the Blankenstein Hospital in Hattingen and was scientifically evaluated by the Chair of Medical Theory and Complementary Medicine of Witten/Herdecke University. This evaluation began on July $1^{\text {st }} 1999$ and was completed on March 31 th 2003. It focused on the following question: "How does a three-week in-patient treatment with naturopathic methods affect the QoL of the patients, regarding a pre-post-comparison and a followup carried out after 6 months? Detailed information concerning this model project and its' scientific evaluation can be found in [13] and [14].

In total, 2,461 patients between 16 and 92 years (mean age $58.0 \pm 13.4$ years) were included in this study. The socio-demographic characteristics of the patients are shown in Table 1. 
Table I: Socio-demographic data of the patient population

\begin{tabular}{|c|c|c|c|c|c|c|c|}
\hline \multirow{5}{*}{ age } & \multirow{5}{*}{$\begin{array}{l}\text { mean } \\
\text { standard deviation } \\
\text { range }\end{array}$} & \multicolumn{2}{|c|}{ male $(n=507)$} & \multicolumn{2}{|c|}{ female $(n=1954)$} & \multicolumn{2}{|c|}{ total $(n=246 I)$} \\
\hline & & \multicolumn{2}{|c|}{58,6} & \multicolumn{2}{|c|}{57,9} & \multicolumn{2}{|c|}{58,0} \\
\hline & & \multicolumn{2}{|c|}{13,4} & \multicolumn{2}{|c|}{13,4} & \multicolumn{2}{|c|}{13,4} \\
\hline & & \multicolumn{2}{|c|}{$17-92$} & \multicolumn{2}{|c|}{$16-92$} & \multicolumn{2}{|c|}{$16-92$} \\
\hline & & $\mathbf{n}$ & $\%$ & $\mathbf{n}$ & $\%$ & $\mathbf{n}$ & $\%$ \\
\hline \multirow[t]{6}{*}{ age group } & under 18 years & 1 & 0.2 & 3 & 0.2 & 4 & 0.2 \\
\hline & $18-45$ years & 89 & 17.6 & 346 & 17.7 & 435 & 17.7 \\
\hline & $45-60$ years & 162 & 32.0 & 676 & 34.6 & 838 & 34.1 \\
\hline & $60-65$ years & 81 & 16.0 & 308 & 15.8 & 389 & 15.8 \\
\hline & 65 and older & 172 & 33.9 & 619 & 31.7 & 791 & 32.1 \\
\hline & no details available & 2 & 0.4 & 2 & 0.1 & 4 & 0.2 \\
\hline \multirow[t]{6}{*}{ diagnostic groups } & connective tissue and soft tissue disorders & 267 & 52.7 & 1305 & 66.8 & 1572 & 63.9 \\
\hline & chronic disorders of the respiratory system & 35 & 6.9 & 60 & 3.1 & 95 & 3.9 \\
\hline & metabolic and nutritional disorders & 92 & 18.1 & 133 & 6.8 & 225 & 9.1 \\
\hline & hypersensitivity reactions & 8 & 1.6 & 46 & 2.4 & 54 & 2.2 \\
\hline & other indications & 85 & 16.8 & 364 & 18.6 & 449 & 18.2 \\
\hline & no details available & 20 & 3.9 & 46 & 2.4 & 66 & 2.7 \\
\hline \multirow[t]{7}{*}{ marital status } & single & 56 & 11.0 & 178 & 9.1 & 234 & 9.5 \\
\hline & married & 352 & 69.4 & 1055 & 54.0 & 1407 & 57.2 \\
\hline & living separated & 7 & $\mathrm{I} .4$ & 34 & 1.7 & 41 & 1.7 \\
\hline & divorced & 37 & 7.3 & 227 & 11.6 & 264 & 10.7 \\
\hline & widowed & 36 & 7.1 & 399 & 20.4 & 435 & 17.7 \\
\hline & second marriage & 12 & 2.4 & 28 & 1.4 & 40 & 1.6 \\
\hline & no details available & 7 & 1.4 & 33 & 1.7 & 40 & 1.6 \\
\hline \multirow[t]{8}{*}{ education } & still at school & 2 & 0.4 & 7 & 0.4 & 9 & 0.4 \\
\hline & no final exam & 15 & 3.0 & 33 & 1.7 & 48 & 2.0 \\
\hline & special school exams & I & 0.2 & 5 & 0.3 & 6 & 0.2 \\
\hline & secondary school exams other than GCSE & 338 & 66.7 & 1191 & 61.0 & 1529 & 62.1 \\
\hline & GCSE ? & 80 & 15.8 & 431 & 22.1 & 511 & 20,8 \\
\hline & A levels & 60 & 11.8 & 201 & 10.3 & 261 & 10.6 \\
\hline & other & 1 & 0.2 & 27 & 1.4 & 28 & I.I \\
\hline & no details available & 10 & 2.0 & 59 & 3.0 & 69 & 2.8 \\
\hline \multirow[t]{6}{*}{ most recent profession } & worker & 206 & 40.6 & 338 & 17.3 & 544 & 22.1 \\
\hline & employee/civil servant & 212 & 41.7 & 941 & 48.2 & 1153 & 46.9 \\
\hline & self employed & 42 & 8.3 & 94 & 4.8 & 136 & 5.5 \\
\hline & not working & 15 & 3.0 & 242 & 12.4 & 257 & 10.4 \\
\hline & unclear & I & 0.2 & 23 & 1.2 & 24 & 1.0 \\
\hline & no details available & 31 & 6.1 & 316 & 16.2 & 347 & 14.1 \\
\hline \multirow[t]{7}{*}{ professional situation } & full-time professional & 142 & 280 & 311 & 15.9 & 453 & 18.4 \\
\hline & part-time professional & 19 & 3.8 & 288 & 14.8 & 307 & 12.4 \\
\hline & housewife/husband & 12 & 2.4 & 484 & 24.8 & 496 & 20.2 \\
\hline & in training & 4 & 0.8 & 13 & 0.7 & 17 & 0.7 \\
\hline & retired pre retired state & 267 & 49.6 & 670 & 33.3 & 937 & 38.2 \\
\hline & unemployed & 46 & 9.1 & 115 & 5.9 & 161 & 6.6 \\
\hline & no details available & 17 & 3.4 & 73 & 3.7 & 90 & 3.7 \\
\hline
\end{tabular}

Alongside the HLQ, other standardized questionnaires were used. These included the MOS-SF-36 Health Survey [15], Zerssen's Mood-Scale Bf-S [16], the Giessener Physical Complaints Questionnaire GBB-24 [17] and McGill's Pain Perception Scale SES [18].

The HLQ as referred to in this study uses 39 five-point likert scales ranging from 0 to 4 (agreement/disagreement or often/never). In contrast to the SF-36, the items are not defined by situations related to daily life and household situations (shopping, career situations, physical activity). As a result, the HLQ is very suitable for registering QoL particularly in monitoring the course of a disease or therapeutic intervention [19]. As an evaluation scheme, Schulte et al. [10] described 5 scales of the 39 item HLQ, unfortunately without any confirmation by factor analysis 
Table 2: Descriptive statistics and reliability parameters of HLQ-Items

\begin{tabular}{|c|c|c|c|c|c|c|c|c|c|c|c|}
\hline \multirow{3}{*}{$\begin{array}{l}\text { Item } \\
\text { No. }\end{array}$} & \multirow[t]{3}{*}{ Item } & \multirow[t]{3}{*}{ Mean } & \multirow[t]{3}{*}{ SD } & \multirow{3}{*}{$\begin{array}{l}\text { Item-Diff. } \\
\text { Index }\end{array}$} & \multirow[t]{3}{*}{ loading } & \multicolumn{3}{|c|}{ Cronbach's $\alpha$} & \multicolumn{2}{|c|}{$\mathbf{r}_{\text {Item-total }}$} & \multirow{3}{*}{$\begin{array}{l}\text { old } \\
\text { Scale }\end{array}$} \\
\hline & & & & & & \multicolumn{2}{|c|}{ Total } & \multirow[t]{2}{*}{ Scale-wise } & & & \\
\hline & & & & & & long & short & & long & short & \\
\hline & Initiative Power \& Interest & & & & & & & 0.885 & & & \\
\hline $10 *$ & good ideas & 2.26 & 0.94 & 0.57 & 0.747 & 0.933 & 0.852 & 0.875 & 0.54 & 0.49 & 3 \\
\hline $07^{*}$ & reacted spontaneously & 2.13 & 1.08 & 0.53 & 0.640 & 0.934 & 0.855 & 0.880 & 0.47 & 0.42 & 3 \\
\hline $1 I^{*}$ & concerned & 2.72 & 1.02 & 0.68 & 0.630 & 0.932 & 0.846 & $0.87 \mid$ & 0.67 & 0.61 & 3 \\
\hline $08^{*}$ & decisive & 2.44 & 0.91 & 0.61 & 0.617 & 0.934 & 0.852 & 0.876 & 0.54 & 0.48 & 4 \\
\hline 12 & put plans into action & 2.09 & 0.91 & 0.52 & 0.572 & 0.933 & & 0.877 & 0.58 & & 4 \\
\hline 25 & difficult to take the initiative & 2.33 & 1.12 & 0.58 & 0.535 & 0.932 & & 0.873 & 0.65 & & 4 \\
\hline 36 & enhanced personally & 2.02 & 1.11 & 0.51 & 0.531 & 0.934 & & 0.881 & 0.47 & & 4 \\
\hline 34 & adapt to other people and situations & 2.79 & 0.81 & 0.70 & 0.530 & 0.934 & & 0.878 & 0.50 & & 3 \\
\hline 33 & asserted in the environment & 2.48 & 0.96 & 0.62 & 0.519 & 0.933 & & 0.876 & 0.55 & & 4 \\
\hline 17 & felt secure & 2.36 & 0.95 & 0.59 & 0.481 & 0.932 & & 0.874 & 0.66 & & 4 \\
\hline 21 & future was clear & 2.21 & 1.14 & 0.55 & 0.455 & 0.933 & & 0.879 & 0.56 & & 4 \\
\hline 06 & sought contact to others & 2.27 & 1.10 & 0.57 & 0.453 & 0.935 & & 0.884 & 0.41 & & 5 \\
\hline \multirow[t]{2}{*}{30} & felt enterprising/energetic & 2.01 & 1.05 & 0.50 & 0.431 & 0.932 & & 0.876 & 0.66 & & 3 \\
\hline & Social Interaction & & & & & & & 0.812 & & & \\
\hline $16^{*}$ & felt left out & 2.79 & 1.07 & 0.70 & 0.697 & 0.933 & 0.850 & 0.775 & 0.57 & 0.52 & 5 \\
\hline $27^{*}$ & felt over-directed & 2.90 & 1.10 & 0.73 & 0.636 & 0.933 & 0.853 & 0.780 & 0.57 & 0.51 & 4 \\
\hline $20 *$ & abandoned community life & 2.51 & 1.12 & 0.63 & 0.631 & 0.932 & 0.847 & 0.766 & 0.66 & 0.59 & 5 \\
\hline 18 & family life was a burden & 2.92 & 1.18 & 0.73 & 0.546 & 0.934 & & 0.792 & 0.52 & & 5 \\
\hline 32 & $\begin{array}{l}\text { didn't feel comfortable in the company of } \\
\text { others }\end{array}$ & 2.31 & 1.10 & 0.58 & 0.532 & 0.934 & & 0.808 & 0.46 & & 5 \\
\hline 28 & convey feelings to other & 2.63 & 0.92 & 0.66 & 0.496 & 0.933 & & 0.788 & 0.57 & & 5 \\
\hline \multirow[t]{2}{*}{05} & anxious/fearful & 2.42 & 1.20 & 0.61 & 0.461 & 0.933 & & 0.797 & 0.56 & & 3 \\
\hline & Mental Balance & & & & & & & 0.812 & & & \\
\hline $35^{*}$ & nervous / irascibly & 1.99 & 1.06 & 0.50 & 0.640 & 0.934 & 0.858 & 0.803 & 0.47 & 0.40 & 3 \\
\hline $26 *$ & well-balanced & 2.01 & 0.97 & 0.50 & 0.600 & 0.932 & 0.850 & 0.770 & 0.67 & 0.61 & 3 \\
\hline $19 *$ & exhausted & 1.24 & 0.94 & 0.31 & 0.567 & 0.933 & 0.849 & 0.782 & 0.59 & 0.56 & 2 \\
\hline 09 & could recover myself & 1.57 & 0.99 & 0.39 & 0.557 & 0.933 & & 0.784 & 0.55 & & 2 \\
\hline 31 & tired & 1.38 & 0.92 & 0.35 & 0.554 & 0.933 & & 0.784 & 0.57 & & 2 \\
\hline 39 & I happy & 2.10 & 0.90 & 0.53 & 0.499 & 0.932 & & 0.781 & 0.69 & & 3 \\
\hline \multirow[t]{2}{*}{04} & sleep was refreshing & 1.55 & 1.05 & 0.39 & 0.356 & 0.935 & & 0.809 & 0.42 & & 2 \\
\hline & Motility & & & & & & & $0.78 I$ & & & \\
\hline $22 *$ & physically agile & 1.95 & 1.02 & 0.49 & 0.789 & 0.935 & 0.854 & 0.708 & 0.40 & 0.43 & $\mathbf{I}$ \\
\hline $24^{*}$ & movement was light & 1.84 & 1.07 & 0.46 & 0.786 & 0.934 & 0.851 & 0.673 & 0.47 & 0.46 & I \\
\hline $38^{*}$ & arms and legs felt heavy & 1.36 & 1.07 & 0.34 & 0.668 & 0.935 & 0.855 & 0.571 & 0.39 & 0.42 & $\mathbf{I}$ \\
\hline \multirow[t]{2}{*}{37} & powerful & $\mathrm{I} .47$ & 0.95 & 0.37 & 0.509 & 0.933 & & 0.482 & 0.56 & & 2 \\
\hline & Physical Complaints & & & & & & & 0.692 & & & \\
\hline $02 *$ & suffered from physical pain & 1.04 & 0.97 & 0.26 & 0.726 & 0.936 & 0.859 & $*$ & 0.27 & 0.32 & $\mathbf{I}$ \\
\hline \multirow[t]{2}{*}{$0 I^{*}$} & felt ill & 1.09 & 0.91 & 0.27 & 0.705 & 0.935 & 0.853 & $*$ & 0.42 & 0.44 & 2 \\
\hline & Digestive Well-Being & & & & & & & 0.621 & & & \\
\hline 03* & good appetite & 2.71 & 1.12 & 0.68 & 0.763 & 0.935 & 0.857 & $*$ & 0.37 & 0.38 & 2 \\
\hline $23^{*}$ & mealtimes were a burden & 2.87 & 1.10 & 0.72 & 0.734 & 0.934 & 0.853 & $*$ & 0.45 & 0.46 & 2 \\
\hline
\end{tabular}

number of answered items ranged from 2,227 [min.] and 2,430 [max.]

* Short form Item

of the following areas: Physical Well-being (4 items), Vitality (9 items), Mental behavior (10 items), Presence of Personality (9 items), Social Environment (7 items). All scales are expressed in percentage values from $0=$ lowest to $100=$ highest QoL.
The main question of this study relates to the re-examination of the HLQ by means of a factor and reliability analysis and the explorative evaluation of the factors. External validation was performed by correlating the HLQ scales with those of the external test instruments: MOS-SF-36 Health Survey [15], Zerssen's Mood-Scale Bf-S [16], the 
Table 3: Partial Correlation of HLQ-Scales with other instruments and with the HLQ-Scales (old adjusted for Gender and Age. Abbrev.: SF-36: PF-physical function, RP-role physical, BP-bodily pain, GH-general health, VT-vitality, SF-social function, RE-role emotional, MH-mental health, MCS-mental component summary, PCS-physical component summary; GBB: SE-severity of exhaustion, GS-gastric symptoms, LP-limb pain, and HS-heart symptoms;, Zerssen's Mood Scale Bf-S; SES: AFF-Affective Pain, SENSSenSory Pain; HLQ-OLD: PWB-physical well-being, VIT-vitality, MEB-mental behaviour, PERS-presence of personality, SOC-Social Environment.

\begin{tabular}{|c|c|c|c|c|c|c|c|c|c|c|c|c|c|}
\hline & & \multicolumn{2}{|c|}{$\begin{array}{l}\text { Initiative Power } \\
\text { and Interest }\end{array}$} & \multicolumn{2}{|c|}{$\begin{array}{c}\text { Social } \\
\text { Interaction }\end{array}$} & \multicolumn{2}{|c|}{ Mental Balance } & \multicolumn{2}{|c|}{ Motility } & \multicolumn{2}{|c|}{$\begin{array}{c}\text { Physical } \\
\text { Complaints }\end{array}$} & \multicolumn{2}{|c|}{$\begin{array}{c}\text { Digestive Well- } \\
\text { Being }\end{array}$} \\
\hline & & long & short & long & short & Long & short & long & short & long & Short & long & short \\
\hline \multirow[t]{10}{*}{ SF-36 } & PF & 0.200 & 0.130 & 0.219 & 0.188 & 0.233 & 0.173 & 0.551 & 0.580 & 0.432 & $*$ & 0.167 & $*$ \\
\hline & $\mathbf{R P}$ & 0.234 & 0.178 & 0.252 & 0.226 & 0.294 & 0.257 & 0.461 & 0.453 & 0.403 & $*$ & 0.184 & $*$ \\
\hline & BP & 0.182 & 0.147 & 0.213 & 0.198 & 0.301 & 0.242 & 0.449 & 0.466 & 0.688 & $*$ & 0.183 & $*$ \\
\hline & $\mathbf{G H}$ & 0.358 & 0.288 & 0.363 & 0.308 & 0.361 & 0.322 & 0.353 & 0.332 & 0.350 & $*$ & 0.208 & $*$ \\
\hline & VT & 0.562 & 0.470 & 0.532 & 0.479 & 0.668 & 0.582 & 0.541 & 0.478 & 0.408 & * & 0.353 & $*$ \\
\hline & SF & 0.543 & 0.437 & 0.632 & 0.589 & 0.550 & 0.486 & 0.392 & 0.342 & 0.337 & $*$ & 0.324 & $*$ \\
\hline & RE & 0.452 & 0.380 & 0.497 & 0.418 & 0.428 & 0.423 & 0.264 & 0.215 & 0.259 & $*$ & 0.243 & $*$ \\
\hline & MH & 0.650 & 0.543 & 0.686 & 0.605 & 0.719 & 0.690 & 0.378 & 0.316 & 0.324 & $*$ & 0.360 & $*$ \\
\hline & MCS & 0.650 & 0.548 & 0.698 & 0.615 & 0.667 & 0.640 & 0.294 & 0.213 & 0.245 & $*$ & 0.348 & $*$ \\
\hline & PCS & 0.020 & -0.012 & 0.022 & 0.025 & 0.087 & 0.024 & 0.489 & 0.530 & 0.497 & $*$ & 0.089 & $*$ \\
\hline \multirow[t]{4}{*}{ GBB 24} & SE & 0.458 & 0.363 & 0.513 & 0.457 & 0.626 & 0.546 & 0.559 & 0.496 & 0.387 & $*$ & 0.323 & $*$ \\
\hline & GS & 0.216 & 0.189 & 0.266 & 0.2277 & 0.303 & 0.247 & 0.205 & 0.166 & 0.238 & $*$ & 0.356 & $*$ \\
\hline & LP & 0.249 & 0.201 & 0.296 & 0.263 & 0.386 & 0.312 & 0.490 & 0.498 & 0.514 & $*$ & 0.190 & $*$ \\
\hline & HS & 0.305 & 0.249 & 0.360 & 0.285 & 0.372 & 0.342 & 0.282 & 0.252 & 0.248 & $*$ & 0.309 & $*$ \\
\hline Bf-S & & 0.655 & 0.564 & 0.652 & 0.599 & 0.630 & 0.581 & 0.409 & 0.362 & 0.312 & $*$ & 0.339 & $*$ \\
\hline \multirow[t]{2}{*}{ SES } & AFF & 0.289 & 0.231 & 0.314 & 0.277 & 0.371 & 0.325 & 0.374 & 0.372 & 0.506 & $*$ & 0.183 & $*$ \\
\hline & SENS & 0.181 & 0.143 & 0.228 & 0.215 & 0.254 & 0.209 & 0.288 & 0.299 & 0.417 & $*$ & 0.147 & $*$ \\
\hline \multirow{5}{*}{$\begin{array}{l}\text { HLQ- } \\
\text { OLD }\end{array}$} & PWB & 0.357 & 0.270 & 0.335 & 0.333 & 0.489 & 0.412 & 0.929 & 0.958 & 0.638 & $*$ & 0.259 & $*$ \\
\hline & VIT & 0.577 & 0.502 & 0.590 & 0.523 & 0.840 & 0.681 & $0.6 \mathrm{II}$ & 0.517 & 0.560 & $*$ & 0.661 & $*$ \\
\hline & MEB & 0.894 & 0.822 & 0.772 & 0.702 & 0.797 & 0.770 & 0.471 & 0.401 & 0.278 & $*$ & 0.412 & $*$ \\
\hline & PERS & 0.926 & 0.779 & 0.760 & 0.734 & 0.628 & 0.584 & 0.404 & 0.354 & 0.226 & $*$ & 0.342 & $*$ \\
\hline & soc & 0.748 & 0.697 & 0.923 & 0.860 & 0.600 & 0.573 & 0.358 & 0.346 & 0.248 & $*$ & 0.346 & $*$ \\
\hline
\end{tabular}

* values of the long version are identical with short version

Giessener Physical Complaints Questionnaire GBB-24 [17] and McGill's Pain Perception Scale SES [18].

Factor analysis was performed using principal components analysis with Varimax rotation on 35 of the 39 items. The items, \#13 (avoided conflicts), \#14 (behavior of others was unclear to me), \#15 (was glad) and \#29 (reduced sexual activity) were omitted following the positive preliminary results on the reliability of the HLQ by Kroez et al. [20]. To determine the internal consistency of the questionnaire, reliability analysis was performed using Cronbach's alpha. Both factor analysis and reliability analysis were performed for the long and the short version of the HLQ.

For the short form, only relevant items with a factorial weight of $>0.6$ were selected. This method of selection was originally suggested by Grimley [21] and has successfully been applied elsewhere $[22,23]$.. Coefficients of determination (R-square) of short and long form scales were calculated to evaluate the proportion of variance of the original HLQ which can be explained by the short form.

Evaluation of responsiveness of the HLQ over a course of time was achieved by analyzing the change of HLQ-total score from the time of admission to the time of discharge by using a dependent t-test and calculation of Cohen's effect size (ES). Cohen's guidelines were used to classify the magnitude of effect sizes: 0.2 represents a small effect, 0.5 a moderate effect, and 0.8 a large effect.

The statistical data evaluation was performed using the SPSS Version 10.0 program packet. 
Table 4: Comparison of the HLQ-L and the HLQ-S.

\begin{tabular}{|c|c|c|c|c|c|c|c|c|}
\hline & \multirow{2}{*}{$\begin{array}{l}\text { Difference } \\
\text { of means }\end{array}$} & \multicolumn{5}{|c|}{ Percentage of Patients with a mean difference $D$} & \multirow[t]{2}{*}{ Correlation } & \multirow{2}{*}{$\begin{array}{l}\text { Explained } \\
\text { Variance }\end{array}$} \\
\hline & & $<3$ & $3<D<7$ & $\begin{array}{l}7<D \\
<10\end{array}$ & $\begin{array}{c}10<D< \\
20\end{array}$ & $>20$ & & \\
\hline Initiative Power and Interest & 1.20 & $32.9 \%$ & $33.6 \%$ & $15.6 \%$ & $15.8 \%$ & $2.1 \%$ & 0.899 & $81 \%$ \\
\hline Social Interaction & 2.24 & $25.9 \%$ & $27.3 \%$ & $20.1 \%$ & $22.2 \%$ & $4.6 \%$ & 0.909 & $83 \%$ \\
\hline Mental Balance & 1.43 & $27.8 \%$ & $28.3 \%$ & $19.6 \%$ & $20.4 \%$ & $3.9 \%$ & 0.888 & $79 \%$ \\
\hline Motility & 1.43 & $46.5 \%$ & $29.7 \%$ & I I.9\% & $11.1 \%$ & $0.8 \%$ & 0.964 & $93 \%$ \\
\hline Physical Complaints & $*$ & $*$ & $*$ & $*$ & $*$ & $*$ & $*$ & $*$ \\
\hline Digestive well-Being & $*$ & $*$ & $*$ & $*$ & $*$ & $*$ & $*$ & $*$ \\
\hline
\end{tabular}

* values of the long version are identical with short version

\section{Results}

The descriptive statistics of each item, the reliability parameters and the difficulty index are given in Table 2. Considering the high percentage of patients with chronic rheumatic diseases, an item-difficulty index between 0.26 (Item: "I suffered from physical pain") and 0.73 (Items "Family life was a burden" and "I felt over directed") can be regarded as sufficient. This also holds for item-total correlations with values between 0.27 and 0.69 (median: 0.55 ) for the original HLQ and between 0.32 and 0.61 (median: 0.46 ) for the short version (HLQ-S), These correlations are considered to be optimal ranges for psychological test instruments.

The results of the structural analysis of the HLQ-items yielded surprising results. The scales found by factor analysis (Table 2) were only partly congruent with the scalesin the original publication [10]. Instead, we found a new and stable 6-factor-model which fits better with the original data than the original 5-scale model derived by Schulte et al., which used a multitrait analysis approach (developed by Hays et al. [24]). This is underlined by a Kaiser-MeyerOlkin measure of sampling adequacy of 0.957 and a highly significant Bartlett test of sphericity ( $p<0.001)$. The cumulative variance explained by this model is $54.7 \%$.

Correlation analysis (Table 3) of the earlier HLQ scale with the new scale revealed significant correlations between the scales "Social Environment (SOC)" and "Social Interaction (SOCI)" ( $\mathrm{r}=0.923$ for the HLQ-L and $r=0.860$ for the HLQ-S). Unfortunately, such clear correlation between an old HLQ scale with the unique factor of our current analysis was not found with the other scales. However, "physical well-being (PWB)" of the old HLQ correlated well with the new "motility (MOT)" scale
(HLQ-L r $=0.929$ resp. HLQ-S $r=0.958$ ), while the old "vitality (VIT)" scale correlates with the "mental balance scale (MB)" (HLQ-L r $=0.840$ resp. HLQ-S r = 0.681). The old scales "presence of personality (PERS)" and "mental balance (MEB)" are represented well by the new scale "initiative power and interest (IPI)" (See Table 3).

The internal consistency of the instruments (HLQ-L and HLQ-S), both for the total score (Cronbach's $\alpha$ is 0.935 for the HLQ-L and 0.862 for the HLQ-S) as well as for the subscales of the HLQ-L (Cronbach's $\alpha$ between 0.621 and 0.885 ) can be regarded as being excellent. The highest alpha reliability in the HLQ-L was obtained for the "Initiative Power and Interest" scale, the lowest for the 2item scales "Digestive Well-Being" (0.621) and "Physical Complaints" (0.692).

The mean difference between the scales of the HLQ-S and the HLQ-L for all patients is between 1.20 ("Initiative Power and Interest ") and 2.24 points ("Social interaction") on a percentage scale. The absolute differences are clustered in groups and are given in Table 4. Although there is a low overall mean difference, absolute differences greater than 10 percent range between $17.9 \%$ ("Initiative Power and Interest") and 26.8\% ("Social interaction"). However, with correlation coefficients ranging from 0.899 to 0.964 , the proportion of variance of the HLQ-L can be explained by the short form ranges between $79 \%$ and $93 \%$ and thus can be regarded as an adequate proportion for a short version.

The correlation of the HLQ with other test instruments is shown in Table 5. There are acceptable correlations with $\mathrm{r}>0.5$ between the mental-health associated scales from the HLQ with those of the other instruments, for example, the "mental health"-Scale of the SF-36. In detail, the scales 
Table 5: HLQ-scales (Mean \pm SD)) of patients separated into diagnostic-, age-and gender specific groups.

\begin{tabular}{|c|c|c|c|c|c|c|c|c|c|}
\hline & age & gender & $n$ & $\begin{array}{l}\text { Initiative } \\
\text { Power and } \\
\text { Interest }\end{array}$ & $\begin{array}{c}\text { Social } \\
\text { Interaction }\end{array}$ & $\begin{array}{l}\text { Mental } \\
\text { Balance }\end{array}$ & Motility & $\begin{array}{l}\text { Physical } \\
\text { Complaints }\end{array}$ & $\begin{array}{c}\text { Digestive } \\
\text { Well-Being }\end{array}$ \\
\hline \multirow{8}{*}{$\begin{array}{l}\text { Connective tissue and } \\
\text { soft tissue disorders }\end{array}$} & $18-45$ & $M$ & 43 & $56.4 \pm 15.2$ & $67.4 \pm 18.9$ & $42.8 \pm 17,2$ & $42.0 \pm 18.4$ & $25.3 \pm 15.8$ & $73.3 \pm 20.3$ \\
\hline & & $\mathrm{F}$ & $\begin{array}{c}16 \\
7\end{array}$ & $54.0 \pm 15.2$ & $64.2 \pm 19.4$ & $36.8 \pm 15.8$ & $38.7 \pm 19.0$ & $25.6 \pm 17.4$ & $67.4 \pm 22.4$ \\
\hline & $45-60$ & $M$ & $\begin{array}{c}10 \\
0\end{array}$ & $60.7 \pm 16.9$ & $69.9 \pm 18.8$ & $46.4 \pm 16.0$ & $42.8 \pm 17.9$ & $25.9 \pm 14.0$ & $77.0 \pm 19.5$ \\
\hline & & $\mathrm{F}$ & $\begin{array}{c}48 \\
3\end{array}$ & $54.5 \pm 15.1$ & $60.2 \pm 18.9$ & $37.9 \pm 15.1$ & $37.0 \pm 18.4$ & $21.6 \pm 16.9$ & $67.6 \pm 23.3$ \\
\hline & $60-65$ & $M$ & 36 & $64.9 \pm 16.0$ & $73.1 \pm 17.9$ & $47.4 \pm 19.4$ & $41.3 \pm 19.6$ & $29.9 \pm 17.7$ & $79.9 \pm 21.6$ \\
\hline & & $\mathrm{F}$ & $\begin{array}{c}20 \\
8\end{array}$ & $61.0 \pm 15.5$ & $66.9 \pm 18.0$ & $41.9 \pm 15.0$ & $40.3 \pm 17.9$ & $23.7 \pm 16.3$ & $74.3 \pm 19.8$ \\
\hline & $>65$ & $M$ & 86 & $60.7 \pm 16.9$ & $70.7 \pm 18.6$ & $48.0 \pm 16.5$ & $36.9 \pm 20.9$ & $20.1 \pm 19.2$ & $75.1 \pm 23.8$ \\
\hline & & $\mathrm{F}$ & $\begin{array}{c}43 \\
7\end{array}$ & $61.0 \pm 16.2$ & $69.2 \pm 18.0$ & $46.1 \pm 16.8$ & $38.3 \pm 21.4$ & $19.4 \pm 17.6$ & $70.0 \pm 24.7$ \\
\hline \multirow{8}{*}{$\begin{array}{l}\text { Chronic disorders of } \\
\text { the respiratory system }\end{array}$} & $18-45$ & $M$ & 5 & $60.4 \pm 19.2$ & $70.7 \pm 14.6$ & $46.4 \pm 20.0$ & $42.5 \pm 24.6$ & $27.5 \pm 31.1$ & $85.0 \pm 22.4$ \\
\hline & & $\mathrm{F}$ & 12 & $50.2 \pm 9.0$ & $62.2 \pm 23.2$ & $34.8 \pm 12.1$ & $49.0 \pm 17.6$ & $35.4 \pm 19.1$ & $59.4 \pm 30.7$ \\
\hline & $45-60$ & $M$ & 2 & $58.7 \pm 14.9$ & $73.2 \pm 12.6$ & $58.9 \pm 7.6$ & $43.8 \pm 8.9$ & $37.5 \pm 0.00$ & $81.3 \pm 26.5$ \\
\hline & & $\mathrm{F}$ & 14 & $61.9 \pm 11.0$ & $66.6 \pm 14.4$ & $37.9 \pm 10.3$ & $39.4 \pm 18.7$ & $27.9 \pm 17.0$ & $65.2 \pm 18.5$ \\
\hline & $60-65$ & $M$ & 6 & $76.6 \pm 6.9$ & $72.0 \pm 6.5$ & $47.6 \pm 10.5$ & $48.9 \pm 28.1$ & $25.0 \pm 17.7$ & $85.4 \pm 12.3$ \\
\hline & & $\mathrm{F}$ & 12 & $55.1 \pm 17.6$ & $67.7 \pm 16.4$ & $37.9 \pm 16.1$ & $41.7 \pm 16.7$ & $31.8 \pm 20.4$ & $59.4 \pm 35.0$ \\
\hline & $>65$ & $M$ & 22 & $57.0 \pm 18.3$ & $67.7 \pm 20.1$ & $45.9 \pm 18.2$ & $43.2 \pm 23.1$ & $29.4 \pm 22.7$ & $65.3 \pm 27.0$ \\
\hline & & $\mathrm{F}$ & 22 & $56.0 \pm 15.3$ & $67.2 \pm 18.8$ & $42.9 \pm 14.2$ & $48.6 \pm 22.4$ & $31.8 \pm 24.9$ & $69.3 \pm 21.4$ \\
\hline \multirow{8}{*}{$\begin{array}{l}\text { Metabolic and } \\
\text { nutritional disorders }\end{array}$} & $18-45$ & $M$ & 15 & $54.4 \pm 16.2$ & $64.8 \pm 20.9$ & $48.1 \pm 18.5$ & $53.9 \pm 18.4$ & $56.7 \pm 29.8$ & $77.5 \pm 19.0$ \\
\hline & & $\mathrm{F}$ & 24 & $58.1 \pm 14.9$ & $69.3 \pm 21.8$ & $40.7 \pm 13.6$ & $45.3 \pm 20.5$ & $42.4 \pm 28.4$ & $64.1 \pm 25.4$ \\
\hline & $45-60$ & $M$ & 25 & $55.9 \pm 16.3$ & $71.4 \pm 18.3$ & $45.8 \pm 14.8$ & $40.8 \pm 16.4$ & $43.0 \pm 27.3$ & $75.5 \pm 21.5$ \\
\hline & & $\mathrm{F}$ & 40 & $59.4 \pm 16.7$ & $65.9 \pm 18.4$ & $44.1 \pm 17.6$ & $46.3 \pm 20.4$ & $39.1 \pm 24.1$ & $72.8 \pm 24.0$ \\
\hline & $60-65$ & $M$ & 20 & $70.9 \pm 12.6$ & $81.6 \pm 13.0$ & $56.7 \pm 14.8$ & $53.7 \pm 18.4$ & $38.1 \pm 21.3$ & $80.0 \pm 15.9$ \\
\hline & & $\mathrm{F}$ & 16 & $67.9 \pm 10.4$ & $74.3 \pm 15.2$ & $54.2 \pm 10.7$ & $44.9 \pm 21.8$ & $39.1 \pm 28.5$ & $83.6 \pm 15.6$ \\
\hline & $>65$ & $M$ & 32 & $66.2 \pm 15.0$ & $75.8 \pm 14.8$ & $53.0 \pm 14.6$ & $49.5 \pm 22.3$ & $41.8 \pm 19.7$ & $79.3 \pm 19.5$ \\
\hline & & $\mathrm{F}$ & 53 & $62.1 \pm 17.3$ & $70.6 \pm 16.6$ & $50.9 \pm 19.3$ & $45.3 \pm 23.2$ & $30.9 \pm 25.2$ & $76.2 \pm 20.3$ \\
\hline \multirow{8}{*}{$\begin{array}{l}\text { Hypersensitivity and } \\
\text { allergic reactions }\end{array}$} & $18-45$ & M & 4 & $59.1 \pm 10.5$ & $68.8 \pm 14.7$ & $53.6 \pm 28.1$ & $64.1 \pm 16.4$ & $28.1 \pm 12.0$ & $68.7 \pm 26.0$ \\
\hline & & $\mathrm{F}$ & 16 & $63.3 \pm 17.1$ & $73.8 \pm 17.8$ & $38.3 \pm 16.2$ & $46.9 \pm 20.9$ & $45.3 \pm 29.5$ & $67.2 \pm 26.6$ \\
\hline & $45-60$ & $M$ & 2 & $55.8 \pm 35.4$ & $62.5 \pm 42.9$ & $51.8 \pm 37.9$ & $43.8 \pm 44.2$ & $25.0 \pm 35.4$ & $87.5 \pm 17.7$ \\
\hline & & $\mathrm{F}$ & 15 & $58.1 \pm 14.6$ & $69.9 \pm 16.2$ & $42.3 \pm 16.1$ & $48.8 \pm 17.9$ & $37.5 \pm 22.2$ & $61.7 \pm 25.6$ \\
\hline & $60-65$ & $M$ & - & - & - & - & - & - & - \\
\hline & & $\mathrm{F}$ & 8 & $51.8 \pm 18.1$ & $62.1 \pm 22.4$ & $32.5 \pm 11.1$ & $52.3 \pm 17.0$ & $28.1 \pm 16.0$ & $62.5 \pm 25.0$ \\
\hline & $>65$ & $M$ & - & - & - & - & - & - & - \\
\hline & & $\mathrm{F}$ & 6 & $71.3 \pm 12.9$ & $77.0 \pm 7.1$ & $55.2 \pm 22.3$ & $60.4 \pm 21.2$ & $22.9 \pm 12.3$ & $83.3 \pm 18.8$ \\
\hline \multirow[t]{8}{*}{ other indications } & $18-45$ & $M$ & 18 & $47.6 \pm 17.5$ & $62.9 \pm 15.6$ & $40.7 \pm 16.1$ & $48.6 \pm 18.4$ & $35.4 \pm 16.7$ & $63.2 \pm 23.3$ \\
\hline & & $\mathrm{F}$ & $\begin{array}{c}12 \\
2\end{array}$ & $53.8 \pm 17.0$ & $60.1 \pm 19.8$ & $35.2 \pm 16.3$ & $46.6 \pm 21.5$ & $35.9 \pm 24.0$ & $59.8 \pm 24.2$ \\
\hline & $45-60$ & $M$ & 28 & $57.2 \pm 16.8$ & $64.3 \pm 25.0$ & $41.8 \pm 16.1$ & $40.6 \pm 19.1$ & $34.8 \pm 19.1$ & $67.4 \pm 27.1$ \\
\hline & & $\mathrm{F}$ & $\begin{array}{l}11 \\
1\end{array}$ & $53.3 \pm 17.0$ & $58.1 \pm 18.4$ & $35.1 \pm 14.1$ & $43.9 \pm 19.5$ & $31.3 \pm 19.6$ & $59.8 \pm 25.1$ \\
\hline & $60-65$ & $M$ & 15 & $55.3 \pm 16.8$ & $69.5 \pm 14.1$ & $44.8 \pm 16.8$ & $45.4 \pm 18.8$ & $40.8 \pm 28.9$ & $71.7 \pm 21.9$ \\
\hline & & $\mathrm{F}$ & 50 & $53.4 \pm 18.1$ & $58.4 \pm 17.3$ & $40.4 \pm 14.7$ & $49.6 \pm 19.0$ & $31.5 \pm 20.7$ & $63.0 \pm 26.5$ \\
\hline & $>65$ & $M$ & 23 & $65.8 \pm 18.8$ & $72.5 \pm 16.7$ & $52.8 \pm 16.5$ & $52.5 \pm 24.6$ & $34.2 \pm 27.5$ & $83.2 \pm 19.4$ \\
\hline & & $\mathrm{F}$ & 78 & $59.0 \pm 17.6$ & $69.0 \pm 18.9$ & $47.8 \pm 16.9$ & $50.6 \pm 21.8$ & $30.2 \pm 27.0$ & $70.7 \pm 26.6$ \\
\hline
\end{tabular}


Table 6: Responsiveness of HLQ-scales measured with Cohen's effect size.

\begin{tabular}{|c|c|c|c|c|}
\hline & $\begin{array}{l}\text { Mean Difference [95\% } \\
\text { CI] (Admission- } \\
\text { Discharge) }\end{array}$ & t-value & $\mathbf{N}$ & Effect-Size ES \\
\hline $\begin{array}{l}\text { Initiative Power and } \\
\text { Interest }\end{array}$ & $8.1[7.4 ; 8.7]$ & 24.89 & 2064 & 0.55 \\
\hline Social Interaction & $11.0[10.3 ; 11.7]$ & 30.18 & 2062 & 0.67 \\
\hline Mental Balance & $15.8[15.1 ; 16.5]$ & 41.75 & 2066 & 0.92 \\
\hline Motility & $11.4[10.6 ; 12.3]$ & 25.49 & 2050 & 0.57 \\
\hline Physical Complaints & $21.7[20.6 ; 22.8]$ & 39.96 & 2022 & 0.89 \\
\hline Digestive well-Being & $9.8[8.7 ; 10.9]$ & 17.78 & 2053 & 0.39 \\
\hline
\end{tabular}

"Initiative Power and Interest", "Social Interaction" and "Mental Balance" of the HLQ correlate well with "mental health" and the "mental component summary", "Social Functionand "Vitality" of the SF-36 and Zerssens Bf-S Mood-Scale. The "motility" scale of the HLQ correlates with "physical function" and "vitality" of the SF-36, with the "severity of exhaustion" of the Giessener Physical Complaints Questionnaire GBB 24, and somewhat weaker with the "role physical", "bodily pain" and "physical component summary" scales of SF-36 and "limp pain" of the GBB 24. The "physical complaints" subscale of the HLQ correlates well with "bodily pain" of the SF-36 and its "physical component summary" scale, and also with the "affection pain" subscale of McGill's Pain Perception Scales SES. Among the SF-36 scales, the factor "general health" is not represented by the HLQ scales. The factors, "gastric symptoms" and the "heart symptoms" from the GBB 24 scales and "sensory pain" from the SES are not represented by the HLQ.

According to the diagnostic spectrum (Table 5), the values of the scale "Motility (MOT)" and "Physical Complaints (PHY)" show particularly low values in patients suffering from rheumatic diseases. Also, in contrast with other scales of the HLQ, these two appear to have little correlation with age, which indicates a suitable discriminatory power of the HLQ considering age and different types of disease.

The results from the responsiveness analysis are presented in Table 6. We found a high sensitivity of the HLQ-scales to change within the treatment with particularly high significant changes in the mean and calculated effect sizes between 0.39 (Digestive Well Being) and 0.92 (Mental Balance).

\section{Discussion}

The aim of our study was to confirm the structure and consistency of the HLQ. Surprisingly, we found that the original scales presented earlier [10] were not in accordance with the results of this factor analysis. However, the scales "IPI-Initiative Power and Interest", "SOCI - Social Interaction", "MB - Mental Balance", "MOT - Motility", "PHYPhysical Complaints", "DWB - Digestive Well-Being" show a good reliability and sufficiently differentiate the diagnostic groups, especially between those patients suffering with connective tissue and soft tissue disorders from those with metabolic and nutritional disorders or hypersensitivity reactions.

Although the HLQ sub-scales "Initiative Power and Interest", "Social Interaction" and "Mental Balance" of the HLQ correlate well with the corresponding SF-36 scales and with Zerssens Bf-S Mood-Scale, and thus indicate that these qualities share several interconnections, our findings also showed that the HLQ provides several aspects of health such as "Appetite and Digestive Affections" which are not well covered by existing QoL-measures. Nevertheless, with only two items, the subscale "digestive wellbeing" has to be strengthened by additional items. This is also true for the scale related to physical complaints and pain. With correlation values of 0.11 (physical total scale of the SF-36) and 0.29 (sensory pain SES), it is quite obvious that this scale is deficient and needs an upgrade in respect to quality and number of items.

As, according to [25] internal consistency reliability is a poor predictor of responsiveness, we measured the responsiveness of the HLQ directly using Cohen's effect size. Together with the highly significant results of the ttest statistics and being aware of the methodological limitations which are immanent in obtaining results on a questionnaires responsiveness by means of effect sizes [26], we can nevertheless conclude that the HLQ shows sufficient responsiveness for the use in a clinical setting.

In our opinion, the HLQ is more sensitive to health changes brought about by Complementary Therapies including anthroposophic medicine or homeopathy. This does not mean that the HLQ is only suitable for such ther- 
apies. Although, there is a trend to consider QoL-questionnaires being specific for special complementary therapies such as mistletoe treatment in cancer patients [27], we do not favor such labels, as this might result in an inflation of "new" QoL-measures for each new therapeutic situation [28].

QoL is a multidimensional construct composed of functional, physical, emotional, social and spiritual well-being $[29,30]$ with, several interconnections between distinct constructs of well-being. The HLQ scales "Social Interaction", "Mental Balance", "Motility", and "Physical Complaints" share similarities with the these constructs, but highlights two further significant topics, i.e. "Initiative Power and Interest" and "Digestive Well-Being". The highly relevant topic of spirituality and illness is addressed in another instrument developed by our group, the SpREUK questionnaire, with its sub-scales "Search for meaningful support", "Positive interpretation of disease", "Trust in external guidance", "Support through spirituality/religiosity" [22,31,32].

Our evaluation indicates an adequate representation of aspects like "mental well-being" and "depression" which are essential in defining QoL, and shows special features of the HLQ that highlights its' uniqueness in the group of generic QoL-measures. Particularly in clinical studies in which, because of feasibility or patient compliance the use of huge psychometric test batteries is inappropriate, the HLQ now serves as a economic test-instrument. To conclude, we can state that this study presents necessary foundations and developments for existing and future studies that wish to use the HLQ as a reliable and valid instrument.

\section{Authors' contributions}

TO performed the statistical analysis, was responsible for the methodological setting of the study and has written most parts of the manuscript, $A B$ has written some parts of manuscript, AMB is director of the study centre and was the clinical supervisor, PFM conceived and designed the study. All authors have read and approved the final manuscript.

\section{References}

I. Spitzer WO: State of science 1986: Quality of life and functional status as target variables for research. Journal of Chronic Diseases 1987, 40:465-47I.

2. Frost $\mathrm{MH}$, Sloan JA: Quality of life measurements: a soft outcome - or is it? Am J Manag Care 2002, 8:574-9.

3. Lorenz W, Ollenschläger G, Geraedts M, Gerlach FM, Gandjour A, Helou A, Kirchner H, Koller M, Lauterbach K, Reinauer H, Sitter H, Thomeczek C: Das Leitlinien-Manual. Entwicklung und Implementierung von Leitlinien in der Medizin. ZaeFQ 200I, 95(Suppl I): I-84.

4. Bradley C, Gamsu DS: Guidelines for encouraging psychological well-being: Report of a working group of the World Health Organisation Regional Office for Europe and International Diabetes Federation European Region St Vincent Declara- tion Action Programme for Diabetes. Diabetic Medicine 1994, II:510-516.

5. Patrick DL, Deyo RA: Generic and disease-specific measures in assessing health status and quality of life. Medical Care 1989, 27:217-232.

6. Gold S, Heesen C, Schulz H, Guder U, Mönch A, Gbadamosi J: Disease specific quality of life instruments in multiple sclerosis: Validation of the Hamburg Quality of Life Questionnaire in Multiple Sclerosis (HAQUAMS). Multiple Sclerosis 200I, 7:119-130.

7. Finlay AY, Khan GK: Dermatology Life Quality Index (DLQI) A simple practical measure for routine clinical use. Clinical and Experimental Derm 1994, 19:210-16.

8. Colwell HH, Mathias SD, Pasta DJ, Henning JM, Hunt RH: Development of a health-related quality-of-life questionnaire for individuals with gastroesophageal reflux disease: a validation study. Dig Dis Sci 1999, 44:1376-83.

9. Hannoveraner Konsens: Empfehlungen zur gesundheitsökonomischen Evaluation. Zeitschrift für Allgemeinmedizin 1996, 72:485-490.

10. Schulte M, Kümmell HC: Entwicklung eines Fragebogens zur Lebensqualität auf der Grundlage des anthroposophischen Menschenbildes. Der Merkurstab 1996, 49:109-122.

II. Schulte M, Heckmann C, Kümmell HC: Der Herdecker Fragebogen zur Lebensqualität (HLQ): Entwicklung, Ergebnisse, Verwendungsmöglichkeiten. In Akademische Forschung in der Anthroposophischen Medizin Edited by: Heusser P. Bern: Peter Lang Verlag; 2000:249-253.

12. Doerfler W, Wisniowski C, Gerhard I: Behandlung des klimakterischen Symptomenkomplexes mit der Traditionellen Chinesischen Medizin (TCM). 169. Tagung der Mittelrheinischen Gesellschaft für Geburtshilfe und Gynaekologie, Homburg/Saar, München: Alete Wissenschaftl. Dienst 1997:153.

13. Beer AM, Ostermann T, Matthiessen PF: Evaluation of in-hospital treatment with naturopathic methods - the Blankenstein model. Part I: Patients and therapeutic concepts. Forsch Komplementarmed Klass Naturheilkd 200I, 8:6-13.

14. Ostermann T, Beer AM, Matthiessen PF: Evaluation of inpatient naturopathic treatment - the Blankenstein model. Part II: Effective strength and health status of patients over the course of time. Forsch Komplementarmed Klass Naturheilkd 2002, 9:269-76.

15. Bullinger M, Kirchberger I: SF-36 Fragebogen zum Gesundheitszustand, Handanweisung. Göttingen: Hogrefe Verlag für Psychologie; 1998.

16. Zerssen D: Die Befindlichkeitsskala. Beltz-Test GmbH; 1976.

17. Brähler E, Scheer JW: Der Gießener Beschwerdebogen (GBB). Bern: Verlag Hans Huber; 1995.

18. Geissner E: Die Schmerzempfindungsskala SES - Ein differenziertes und veränderungssensitives Verfahren zur Erfassung chronischer und akuter Schmerzen. Rehabilitation 1995, 34:XXXV-XLIII.

19. Beer AM, Ostermann T, Matthiessen PF: Changes in quality of life during acute inpatient naturopathic treatment - results of the Blankenstein model. Gesundheitswesen 200I, 63:242-247.

20. Kroz M, von Laue HB, Zerm R, Girke M: Development of a questionnaire for endogenous regulation - a contribution for salutogenesis research. Forsch Komplementarmed Klass Naturheilkd 2003, 10:70-77.

21. Grimley DM, Bellis JM, Prochaska JO, Riley GE: Assessing the stages of change and decision making for contraceptive use for the prevention of pregnancy, sexually transmitted diseases, and acquired immunodeficiency syndrome. Health Educ $Q$ 1993, 20:455-470.

22. Büssing A, Ostermann T, Matthiessen PF: Role of Religion and Spirituality in Medical patients - Confirmatory results with the SpREUK questionnaire. Health Quality Life Outcomes 2005, 3:10.

23. Schumacher J, Leppert K, Gunzelmann T, Strauss B, Braehler E: Die Resilienzskala - Ein Fragebogen zur Erfassung der psychischen Widerstandsfähigkeit als Personmerkmal. Z $f$ Klinische Psychologie, Psychiatrie und Psychotherapie 2004, 53:16-39.

24. Hays RD, Hayashi $T$ : Beyond internal consistency reliability: rationale and user's guide for the Multitrait Analysis Pro- 
gram (MAP) on the microcomputer. Behav Res Methods Instrum Comput 1990, 22:167-175.

25. Puhan MA, Bryant D, Guyatt GH, Heels-Ansdell D, Schunemann $H J$ : Internal consistency reliability is a poor predictor of responsiveness. Health and Quality of Life Outcomes 2005, 3:33.

26. Middel B, van Sonderen E: Statistical significant change versus relevant or important change in (quasi) experimental design: Some conceptual and methodological problems in estimating magnitude of intervention-related change in health services research. International Journal of Integrated Care 2002, 2: I-22.

27. Kirchberger I, Wetzel D, Finger T: Development and validation of an instrument to measure the effects of a mistletoe preparation on quality of life of cancer patients: the Life Quality Lectin-53 (LQL-53) Questionnaire. Qual Life Res 2004, 13:463-479.

28. Ostermann T: Fragen zur Mistel. Journal Club. Forsch Komplementärmed 2004, I I:361-62.

29. Peterman AH, Fitchett G, Brady MJ, Hernandez L, Cella D: Measuring spiritual well-being in people with cancer: the functional assessment of chronic illness therapy - Spiritual Well-being Scale (FACIT-Sp). Ann Behav Med 2002, 24:49-58.

30. Brady MJ, Peterman AH, Fitchett G, Mo M, Cella D: A case for including spirituality in quality of life measurement in oncology. Psychooncology 1999, 8:417-428.

31. Ostermann T, Bussing A, Matthiessen PF: Pilot study for the development of a questionnaire for the measuring of the patients' attitude towards spirituality and religiosity and their coping with disease (SpREUK). Forsch Komplementarmed Klass Naturheilkd 2004, I I:346-353.

32. Büssing A, Ostermann T, Matthiessen PF: Search for meaningful support and the meaning of illness in German cancer patients. Anticancer Res 2005, 25: | 449-55.

Publish with Bio Med Central and every scientist can read your work free of charge

"BioMed Central will be the most significant development for disseminating the results of biomedical research in our lifetime. "

Sir Paul Nurse, Cancer Research UK

Your research papers will be:

- available free of charge to the entire biomedical community

- peer reviewed and published immediately upon acceptance

- cited in PubMed and archived on PubMed Central

- yours - you keep the copyright 